\title{
Political Economy of Property Tax Reform: Hawaii's Experiment with Split Rate Property Taxation
}

\author{
Sally Kwak ${ }^{*}$ \\ Department of Economics \\ University of Hawai'i ia Mānoa \\ James Mak ${ }^{* *}$ \\ Department of Economics \\ University of Hawai'i at Mānoa \\ Working Paper No. 09-15 \\ December 7, 2009
}

\begin{abstract}
Economic theory suggests that switching from a general property tax to a split-rate tax increases land use efficiency and stimulates urban core development while preserving the environment and reducing urban sprawl. Under split-rate property taxation, land is typically taxed at a significantly higher rate than improvements. Beginning in 1965 Hawaii experimented with a statewide split-rate property tax system to encourage economic growth and effect land reform. The experiment was ended in 1977. Following the transfer of property taxing powers to the counties in 1978, some counties brought back the split-rate property tax at times. Since 2006, Kauai County has adopted the unusual practice of taxing improvements at a higher rate than land for most property classes. This paper chronicles and explains the rationale behind Hawaii state and county experiments with split rate property taxation.
\end{abstract}

Keywords: Property taxes, split rate property taxation, tourist taxes JEL codes: $H$

\footnotetext{
* Sally Kwak is Assistant Professor of Economics at the University of Hawaii-Manoa, 2424 Maile Way, Rm 542, Honolulu, HI 96822 U.S.A. E-mail: kwaks@hawaii.edu; Ph. (808) 956-8496; Fax: (808) 956-4347. Her research interests are in the economics of education and public finance. Her latest paper focuses on the taxation of timeshare occupancy.

** James Mak is Professor of Economics at the University of Hawaii-Manoa. Ph. (808) 956-8280; Fax (808) 956-4347; E-mail: jmak@hawaii.edu His research interests are in the economics of travel and tourism. His latest book, published in 2008 by the University of Hawaii Press, is entitled Developing a Dream Destination, Tourism and Tourism Policy Planning in Hawaii.

${ }^{\dagger}$ The authors gratefully acknowledge the assistance of Lowell Kalapa (President, Tax Foundation of Hawaii) for sharing with us his wealth of knowledge about the history of split-rate taxation in Hawaii. We also thank Sumner LaCroix, Andrew Kato, and an anonymous referee for valuable comments. Robert Magota of Honolulu County's real property assessment office was extremely helpful in providing information on assessment practices and county ordinances related to property tax assessments in Hawaii. Kwak's work on this paper was supported by the Lincoln Institute of Land Policy.
} 


\section{Introduction}

Nobel laureate in economics William Vickrey once observed that “The property tax is, economically speaking, a combination of one of the worst taxes - the part that is assessed on real estate improvements... and one of the best taxes — the tax on land or site value.” ${ }^{\text {i }}$ Property tax reforms are an important part of ongoing attempts on the part of governments to raise revenue in efficient ways. In the U.S. most local communities tax real property-i.e. land and improvements-- at a single rate. However, a few communities notably in Pennsylvania_-and most famously the city of Pittsburgh-- have experimented with splitting this rate into two components, levying one rate on the value of the land and another on the value of improvements (Hartzok, 1997; Oates and Schwab, 1997). Typically, the tax rate on the value of the land is set significantly higher than that on improvements. ${ }^{\text {ii }}$ Around the world, more than seven hundred cities use the split-rate property tax system (Cohen and Coughlin, 2005, p. 359). In the U.S. the split-rate property tax is currently employed only in sixteen Pennsylvania municipalities and two counties in Hawaii. However, economists favor greater usage of split rate property taxation by local U.S. jurisdictions. Dye and England (2009, p. 10) argue that "Economic theory and, to a lesser degree, empirical evidence support the claim that taxing land values instead of wages, profits, or capital values would improve economic performance and could improve people’s lives.”

Economic theory suggests that switching from a general property tax to a split-rate tax increases land use efficiency and stimulates urban core development while preserving the environment and reducing urban sprawl. Furthermore, the split-rate system is able to achieve these objectives while remaining revenue neutral and minimizing excess burden (Dye and England, 2009; Cohen and Coughlin, 2005). There is growing volume of empirical evidence to 
support the theoretical predictions (See, for example, Banzhaf and Lavery, in print; Dye and England, 2009; Plassman and Tideman, 2000; Oates and Schwab, 1997; and Shoup, 1978.) with more work in progress, notably, at the Lincoln Institute of Land Policy in Cambridge, Massachusetts.

However, the split rate property tax is not without potential problems. Redistribution of the property tax burden following tax reform could arouse political opposition to the change as the burden of higher tax rates on land (relative to improvement) values tends to fall more heavily on owners of properties with higher land to building values (Dye and England, 2009; Chapman and Facer II, 2005; England, 2004; Shoup, 1978). A land value tax can be regressive for many homeowners (England and Zhao, 2005; Bowman and Bell, 2008). ${ }^{\text {iii }}$

Inaccurate property assessments can also undermine the confidence of residents in supporting property tax reform. In 2009, a task force in Philadelphia reviewing the city’s property tax system did not recommend the split-rate property tax in part because of distrust in the assessment system. ${ }^{\text {iv }}$ Accurate assessment of land values separately from improvement (building) values is necessary in a split-rate property tax system but remains a challenge in implementation (Bell, Bowman and German, 2009; Bowman and Bell, 2008; Bell and Bowman, 2008; and Bell, 2006; and England and Zhao, 2005). Brunori and Carr find (2002, p. 2) that 29 states require land and improvements to be valued separately for property tax purposes. ${ }^{\mathrm{v}}$ Of the 244 local government offices that were charged with administrating the local property taxes in these jurisdictions, 86 percent employed some form of comparable sales method, generally examining the sale of comparable vacant or unimproved land. A study conducted by the U.S. Advisory Commission on Intergovernmental Relations (ACIR, 1989, p. 258) of property tax assessment methods employed in Hawaii concluded that Hawaii's approach of separating land 
values from improvement values "overstate the value of land”...because assessors "are required to use the cost approach to value improvements.”vi This abstraction (or extraction) method calculates the land value component of a parcel as a residual by subtracting the depreciated improvement value from the value of the total parcel. The method is frequently used in urban areas that lack sufficient number of land sales to allow comparable sales analysis. Bell, Bowman and German (2009, pp. 173-174) and Bowman (2006, pp. 5-6) note that this method may encounter a number of potential problems that can undermine accurate assessment.

Dye and England (2009) recently compiled an impressive collection of essays that examine the theory, empirical evidence, and practices in land value taxation. This paper contributes to expanding this literature by examining the political economy of Hawaii's experience with split-rate property taxation that began in the 1960s to the recent (2006) adoption of the unusual inverted split-rate property tax on Kauai. ${ }^{\text {vii }}$ As one of two states that has experimented with split-rate property taxation, Hawaii’s experience has not been carefully documented.

Hawaii's experiment with split-rate property taxation is different from that of Pennsylvania because it was initiated at the state level and applied to the entire state. As in other localities where split-rate taxation has been adopted, Hawaii's legislation as passed in 1963 and repealed in 1977, stipulated higher tax rates on land than on improvements. In 1978, the State transferred the power to levy property taxes to the four counties. By fiscal year 1982, all four counties levied a uniform rate (within each county) on land and improvements. Subsequently, some counties readopted the split rate property tax on some property types in some years. Atypically, Honolulu County (1989-1998) and Kauai County (2006 to the present) adopted the unusual practice of taxing improvements at a higher rate than on land on some properties 
resulting in an "inverted" split-rate property tax. In FY 2009, Hawaii County brought back the split-rate property tax but applied it only to two of ten property types, (non-owner occupied) "residential” and "agricultural or native forest” properties.

Section II describes briefly the Hawaii State Legislature’s passage (in 1963) and implementation (in 1965) of a statewide split-rate property tax and its subsequent repeal (in 1977). Section III examines the different approaches to property taxation among the counties after the transfer of taxing powers from the State in 1978 and the re-adoption of the split rate property tax in some counties at various times. Section IV describes the events and reasons leading up to the adoption of the inverted split rate property tax system on Kauai in fiscal year 2006. Section V concludes.

\section{Enactment and Repeal of the Split-Rate Property Tax at the State Level}

The Pittsburgh Tax Plan, modeled on a similar assessment approach used in Pittsburgh, Pennsylvania, was passed by the Hawaii Legislature and signed into law by then Governor of Hawaii, John Burns in June 1963 (Act 142, Session Laws of Hawaii 1963) to take effect on January 1, 1965. Hawaii Revised Statutes, HRS 242, instituted separate rates of property taxation on land and on improvements. The law provided for real estate to be divided into six categories: residential, hotel, commercial, industrial, agricultural, and conservation. Of these, the first four categories would be taxed according to a split-rate system, but agricultural and conservation lands would be excluded.

In the initial discussion of the Pittsburgh Tax Law, the Attorney General's office pointed out that land without a need for extensive improvements, such as agricultural land and conservation land, would be disproportionately burdened by the passage of the bill (Hawaii State Archives, Correspondence of the Attorney General). The Legislature passed legislation (Hawaii 
Revised Statutes Section 8 HRS 248-2) requiring a single rate to be applied to agricultural and conservation properties. In passing the split rate property tax bill, the Legislature also chose to phase in rates according to a graded schedule. Over time, the law increased the difference in rates on land and on improvements until the repeal of the Pittsburgh plan in 1977 (Tax Foundation of Hawaii, various years). viii

Hawaii’s split-rate property tax began under the auspices of the state government due to the highly centralized state and local government system in Hawaii where, until 1978, the State rather than the four county governments in Hawaii controlled the property tax. The State of Hawaii is the last of the 50 states to achieve U.S. statehood in 1959, and until the overthrow of Queen Liliuokalani in 1893, it was a functioning monarchy. Following statehood, the islands were divided politically into four counties: Honolulu, Maui, Kauai, and Hawaii (the Big Island); there are no lower levels of government with taxing powers. Hawaii’s highly centralized form of government today is believed to be a legacy of the monarchy (Meller, 1992). ${ }^{\text {ix }}$

The high degree of centralization in Hawaii's system of state and local government is reflected by the state-level provision of K-12 public education. Public schools in the U.S. are typically funded at the local district level and with significant amounts of local property taxes. However, public K-12 education in Hawaii is provided at the state level. The lack of local education funding in Hawaii obviates the need for local government to levy the high property taxes found in other states. The Hawaii State Constitution also places responsibility for the most costly functions of government at the state level. Thus, the State of Hawaii provides much of the expenditures on welfare, health and hospitals (Tax Foundation of Hawaii, 1969). The state's 1984 Tax Review Commission (p.1) concluded in its analysis of Hawaii fiscal system between 
FY1965 and FY1984 that “Compared to other states, Hawaii is fiscally centralized, with state government playing the dominant role. The degree of centralization has increased over time.”

Throughout the 1960's and 1970's, Hawaii's state and local governments administered sixteen tax laws. Of these, fourteen were administered by the state government. Only the motor vehicle weight tax and the public utility franchise tax were administered by the four local counties (Tax Foundation of Hawaii, 1968, 1969a, 1971-1979). The limited powers to raise revenues led to limited responsibilities on the part of local county governments. The centralization of government function in Hawaii enabled the state to adopt a statewide split-rate property tax system.

The degree of centralization in Hawaii’s system of state and local government shifted somewhat in 1978 when the State Constitutional Convention forced the State to turn over administration of the real property tax to the county governments. ${ }^{x}$ However, with the major expenditure responsibilities—in particular, public school funding—still reserved to the state government, property tax rates remained low in comparison to rates in U.S. mainland states and cities. Using FHA mortgage data, the U.S. Advisory Commission on Intergovernmental Relations (ACIR, 1989, pp. 243-244) estimated that:

...in 1966, Hawaii’s effective property tax rate was 0.81 percent of market value, again well below the national average, which at the time was 1.70 percent. Only four states had a lower effective property tax rate in 1966 than Hawaii (Alabama, Louisiana, South Carolina, and West Virginia).

In 1966 the effective property tax rate in Hawaii was only 48 percent of the national average. The ACIR (1989, p. 243-244) further noted that "between 1966 and 1986, the effective property tax rate fell faster in Hawaii than in the U.S. as a whole.” 
There are two other aspects of Hawaii's history and set of background characteristics which are critical to an understanding of why the State passed (in 1963) and implemented (in 1965) the split rate property tax. In 1959 average income per person in Hawaii was 20 percent below the national average (Mak, 2008, p. 30). The split-rate property tax legislation was intended to further economic growth by taxing idle land at a premium rate and creating a more open, competitive market for land. The 1960's were years of rapid growth in Hawaii's economy driven largely by tourism (Mak, 2008, Chapters 2 and 3; Hitch, 1992). Political historian Tom Coffman (2003, p. 167) opined that “...rapid economic growth was a powerful companion to the Democratic Party's goal of developing a politically progressive, multiracial society.”

The third crucial factor in Hawaii's passage and implementation of the split-rate system was political. The Democrats gained ascendancy in a great electoral victory in 1954 against a backdrop of decades of past Republican rule. The power base of the Republican Party was the Big Five, the consortium of five sugar factors who held most of the economic power and wealth in the islands. The first part of the twentieth century saw a high concentration of wealth, land ownership, and power in the hands of the Republicans. Before World War II, almost half of all the total land area of the Hawaiian islands was held by fewer than 80 private individuals; the rest was largely publicly owned. Most of the agricultural land was also largely owned by the same individuals (Cooper and Daws, 1985, p. 3). Land in Hawaii was more highly concentrated than in any other U.S. urban area (LaCroix and Rose, 1989). Furthermore, the geographical isolation of the islands precluded any substitutes for land in Hawaii (LaCroix and Rose, 1989). Cooper and Daws (1985, p. 2) note that land in Hawaii "has always been a political battleground and prize.”xi 
In contrast to the mainly Caucasian dominated Republican Party, the Democratic Party was multi-ethnic and consisted of many Asian immigrants and their children. ${ }^{\text {xii }}$ They came into office promising land and tax reform (Cooper and Daws, 1985, p.37). This meant “changes in the ownership, taxation, and use of land so as to benefit the ordinary person. And because there was no bigger item than land in Hawaii’s politics, land reform was one of the biggest items on the Democratic agenda” (Cooper and Daws, 1985, p. 5). Shoup (1978, p. 119) argues that Hawaii's high concentration of land ownership may have made it easier politically to adopt the split-rate tax system because there were few landowners who might lose by the switch while there were many more people who would gain.

The Democrats’ platform consisted of three main proposals, one of which was the Pittsburgh Tax Bill. In passing this bill (1963), the Democrats “intended to stimulate construction” by levying a lower property tax rate on assessed building values than on land values (Cooper and Daws, 1985, p. 37). Another intended effect of the Pittsburgh plan was to persuade large landowners to develop their land or to sell them to someone else who would use them (Cooper and Daws, 1985, p. 37). By forcing land onto the market, legislators also hoped to break up the large land estates and produce a more egalitarian distribution of wealth in the

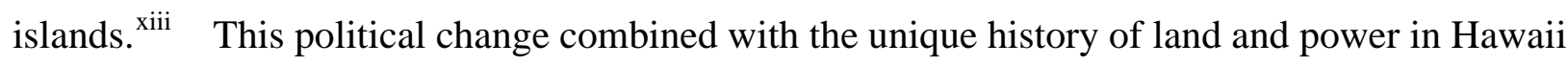
contributed to the eventual implementation of split-rate property taxation.

Table 1 shows that agricultural and conservation lands were not included in the newly installed split rate property tax system in 1965. The arrival of the split rate system in Hawaii was accompanied by higher average property tax rates in all four counties. In 1963, the state-wide average rate was $\$ 14.75$ per $\$ 1000$ net taxable property. In 1965 , the average rate rose to $\$ 17.54$ per \$1000 net taxable property; the rate on land was $\$ 3.42$ cents per $\$ 1,000$ net taxable property 
higher than before the implementation of tax reform while the rate on buildings was $\$ 1.58$ higher. However, the gap between the two in Hawaii was not remotely close to the five-fold or more difference observed in Pittsburgh in 1979-1980 or even effectively the two-fold increase in Pittsburgh when county and school property tax levies are included (Oates and Schwab, 1997).

Although tax rates varied among the four counties, with Hawaii County levying the highest rates and Maui County levying the lowest rates, the tax rate on land was only about 11 percent higher than on improvements for all property types in all four counties, except for industrial properties in Hawaii County where the tax rate on land was nearly 16 percent higher.

In the 1970s, the residential category was further divided into two separate categories: improved and unimproved residential. A single rate applied to improved residential properties while the split rate applied to unimproved residential properties. Where the split rate still applied, the gap between the tax rate on land and improvements had widened, but the rate on land was only 43 percent higher than the rate on buildings in all four counties.

The Pittsburgh Tax law survived for fourteen years. It was eventually repealed as residents' appetite for growth waned in the 1970's (Mak, 2008, Chapter 3). By 1970, per capita personal income in Hawaii exceeded the national average by nearly 25 percent (State of Hawaii Department of Business, Economic Development and Tourism, 2006, Table 13.07.) The advent of statehood in 1959, introduction of jet travel to Hawaii that same year, and the liberalization of outbound tourist travel by Japan, and the robust growth of the U.S. and Japanese economies had quadrupled tourism in a decade, bringing with it large increases in demand for hotel and tourismrelated construction and workers. With the local labor force unable to fill this demand, immigrants filled the labor gap, fueling growing resident discontent and anti-growth sentiments (Mak, 2008, Chapter 3). ${ }^{\text {xiv }}$ During his 1974 successful campaign for governor, Democratic Party 
candidate George Ariyoshi argued that "It is irresponsible for public officials to discuss Hawaii's future in terms of unlimited growth." ${ }^{\text {vv }}$ In the mid-1970s, the state embarked on a massive effort to develop the nation's first comprehensive state development plan (The State Plan) to address perceived problems stemming from economic growth. ${ }^{\text {xvi }}$ Bourassa (2009, p. 197) surmises that land value taxation was abolished in Hawaii because "a high rate of development led to a perception that the tax was too effective and therefore undesirable.”

There were other reasons. The State also experienced significant problems with implementation following passage of the Pittsburgh Tax Plan in 1963. The plan was considered to be overly complicated, opaque, and inequitable. The Honolulu Star Bulletin published articles in 1963 and 1964 reporting on the excessive complexity of the bill. ${ }^{\text {xvi }}$ The State Tax Director wondered how it was going to explain the complex bill to taxpayers. The executive director of the Tax Foundation of Hawaii opined that the complexity of the bill would increase tax collection costs. Then in late December of 1963, the State Tax Department noted that the proposed bill would be unfair to owners of homes built on fee simple land vis-à-vis homes built on leasehold land as the overall tax on fee-simple properties would increase because a higher proportion of their total values was in land while a higher proportion of a leasehold's property was in the building value. The Tax Director asked the Legislature to rectify the mistake as this was not the Legislature's intent. ${ }^{\text {xiii }}$ The Honolulu Chamber of Commerce called for the repeal of the Pittsburgh Plan in 1964 even before the law went into effect.

In 1977, opponents of the split-rate structure won and the legislature repealed the splitrate system, re-instituting and phasing in a single-rate system. ${ }^{\text {xix }}$ In hindsight, Hawaii’s statewide split rate property tax system would have ended anyway after the State turned over the administration of the property tax to the counties in 1978. 


\section{Return of the Split- Rate Property Tax at the County Level}

Repeal of the Pittsburgh Tax Plan in 1977 by the Hawaii State Legislature did not spell the end of the split-rate property tax system in Hawaii. Following the transfer of property taxing powers to the counties in 1978 (Hawaii Revised Statutes HRS 246A-2), each county now sets, assesses, and collects its own property taxes. ${ }^{x x}$ In FY 1982, all four counties in the state employed a single rate structure and applied a single county-specific tax rate on all property types. Average tax rates varied among the four counties. However, by FY1999, three of the four counties—Hawaii, Honolulu, and Kauai—had reinstituted some form of the split-rate property taxation. Maui County alone elected to retain a single rate structure. ${ }^{\mathrm{xxi}}$

\section{Hawaii County}

Between FY1983 and FY2002 Hawaii County imposed a higher tax rate-approximately 20 percent more — on land for all property types except improved residential and homeowner properties. $^{\text {xxii }}$ Thereafter, the county adopted a single rate structure for all properties until FY2009. In FY 2009, Hawaii County brought back the split-rate property tax but applied it only to two of ten property types, (non-owner occupied) "residential” and "agricultural or native forest” properties. The new rates were (and remains currently at) 14 percent higher on land on “residential” properties but 31.5 percent higher on "agricultural or native forests.” (City and County of Honolulu, Real Property Assessment Division, July 29, 2008). This was achieved by keeping the tax rates on land unchanged while reducing the tax rate by $\$ 1$ per $\$ 1,000$ of net taxable assessed valuation on improvements on (non-owner occupied) single family residences (from \$8.10 to \$7.10) and \$2 per \$1,000 of net taxable assessed valuation on improvements on agricultural or native forest lands (from $\$ 8.35$ to $\$ 6.35$ ). The reason for the reduction in the property tax rates on improvements in these two property classifications was to target them 
specifically for tax relief due to large increases in their assessed valuations for FY2009 (Quirk, 2008b; Quirk, 2008c). Assessed values on residential improvements increased by 63 percent between FY2008 and FY2009 and 59 percent on "agricultural and native forest" improvements. By comparison, all other property classifications saw assessed improvement values increase by an average of 11.5 percent between the two years. In public hearings, the most vocal complaints were directed at the sharp increase in agricultural improvement assessments. ${ }^{\text {xxiii }}$ Between FY2008 and FY2009, the gross assessed value of agricultural and native forest lands in the county fell slightly from $\$ 4.67$ billion to $\$ 4.47$ billion while the gross value of improvements on that land increased from $\$ 1.69$ billion to $\$ 2.69$ billion. The increase in the assessed value of improvements was not because there were more properties to tax; indeed the number of records for agricultural/native forest properties actually decreased slightly from 69,426 in FY2008 to 68,913 in FY2009. By law, the county is required to assess properties at 100 percent of their market values, but according to the Hawaii County Real Property Tax Administrator, assessment of improvements had fallen badly behind (Quirk, 2008a). Working in cooperation with the City and County of Honolulu, Hawaii County conducted engineering studies which resulted in the adjustment of the cost tables used to determine building assessments, bringing building assessment values in FY2009 up to 90 percent of market values from 75 percent. Thus, the big jump in assessed building values was a catch-up to market valuation. The Property Tax Administrator explained that land assessments were adjusted a few years ago and hence would remain stable between FY2008 and FY2009. Owners of agricultural properties who resided on their land lobbied for tax relief, noting that homeowners who live in their own homes receive preferential tax treatment from the county's 3 percent cap on annual increases in their property tax assessments. The County Council and the Mayor were in agreement on the need for rate cuts 
(Quirk, 2008c). The new rates were estimated to save taxpayers nearly \$7 million in annual property tax payments (Quirk, 2008c).

\section{Honolulu County}

Honolulu County implemented a single rate structure, except during a 10-year period between FY1989 and FY1998. During this period, the county set higher rates on buildings than

on improved residential properties (see Table 2). ${ }^{\text {xxiv }}$ This was achieved by reducing the tax rate on land from $\$ 6.56$ per $\$ 1,000$ of taxable value to $\$ 6.09$ and keeping the tax rate on improvements unchanged.

\section{[Table 2 around here]}

Table 2 shows that rates on both land and buildings fell during the early ' 90 s. This followed rising housing prices on Oahu in the late '80s. The tight housing market was associated with a decline in the number of available units for sale at any given time during this period (ACIR, 1989, p. 239). The run-up in real estate prices was widely attributed to speculative Japanese real estate investments. ${ }^{\text {xxv }}$ Tax Foundation of Hawaii President Lowell Kalapa recalls that the change in property tax policy on improved residential properties was largely a political “backlash” against the wave of foreign, specifically Japanese, purchases of expensive homes in Honolulu beginning in the late 1980s. ${ }^{\text {xxvi }}$ The University of Hawaii’s Real Estate Research and Education Center found that in one neighborhood, Japanese buyers paid an average of 21 percent over estimated market value. Anecdotally, one Japanese billionaire investor purchased 100 homes in upscale East Honolulu and indicated that his goal was to purchase up to 1,000 homes on Oahu (Mak and Sakai, 1992). He ended up purchasing 180 (Aguiar, 2009). Between 1987 and 1990, the median price of single family homes on Oahu rose from $\$ 185,000$ to $\$ 352,000$ an increase of 90 percent in three years (Mak and Sakai, 1992). While Japanese investments 
may have driven up prices in some neighborhoods, they were not the primary cause of the general housing price inflation in Honolulu. Median housing prices also spiked in the other counties where Japanese investment did not play a significant role in the residential home markets (Scontras, 2009).

Kauai County

Kauai County’s experiment with split-rate property taxation was somewhat different from that of Hawaii and Honolulu counties. Two destructive hurricanes (Iwa in 1982 and Iniki in 1992) caused massive physical and economic damage to Kauai. ${ }^{\text {xxvii }}$ In adopting the split rate property tax, lawmakers on Kauai may have intended to provide fiscal incentives to facilitate reconstruction and generate jobs and income. In any case, between FY1984 and FY2005 land for all property classes was taxed at a higher rate than on improvements. However, beginning in FY2006, the county did an about face and levied higher tax rates on buildings than on land for residential (single family and non-owner occupied apartments), commercial, industrial, and hotel/resort properties. Table 3 compares the structure of property tax rates by county land use classes on Kauai for FY2006 and FY2005.

[Table 3 around here]

The inverted structure of Kauai’s 2006 implementation of split-rate property taxation for five of the eight property classes is, at first glance, puzzling. In the following section, we examine the reasons for its adoption.

\section{Kauai’s Inverted Split Rate Property Tax Structure}

Beginning in late 1998, property values jumped sharply on Kauai (Youn, 2003; Scontras, 2009). Table 4 shows that residential property tax assessments rose rapidly after 2000.

[Table 4 around here] 
The U.S. Advisory Commission on Intergovernmental Relations (ACIR, 1989, p. 239) has observed that historically in Hawaii, "property values have tended to increase more rapidly than incomes.” Following the example of California’s Proposition 13, in 2004 Kauai citizens voted to change the county charter to roll back property tax assessments and to cap annual assessment increases on owner occupied homes. The vote was invalidated by the Hawaii Supreme Court in 2007 (Zimmerman, 2007; Supreme Court of Hawaii, 2007). The County also established a ninemember Real Property Tax Task Force whose mission was "to create a tax model which provides predictability, equity, and clarity." xxviii The Task Force met in over 28 meetings and in October 2004 unveiled a series of specific recommendations. It suggested that the base assessed value of properties be established by the average of assessed values between 1999 and 2003. Thereafter, annual increases would be indexed to the general inflation rate (Honolulu CPI-U). 1999 was chosen as a starting date because property prices on Kauai had begun to escalate in late 1998. It also recommended that the eight different property tax classes be reduced to two: (1) "LongTerm Residential” for properties which are occupied by their owners and/or long term tenants; and (2) "General” for all other properties. Tax rates on "Long-Term Residential” properties would be set at $\$ 2$ for land and $\$ 6$ for buildings for every $\$ 1000$ in assessed value. On "General" properties, the tax rate would be $\$ 4$ for land and $\$ 12$ for buildings for every $\$ 1000$ in assessed value. In sum, buildings would be taxed at rates three times that of land. Exemptions would remain unchanged. The inverted property tax was seen to be a way to provide property tax relief for people who own modest homes and to insulate them against sharply rising land values (Chuan, 2004).

Draft Bill 2108, which incorporated these recommendations, did not receive a public hearing at the County Council because council members felt that it would undermine the 
Council's taxing authority (Finnegan, 2008). Instead, the County Council enacted a temporary fix, capping annual property tax bill increases on homes owned and occupied by residents at two percent, and six percent for residents who put their second homes into long term rentals (Eagle, 2008). The mayor further proposed and the Council reduced tax rates on land for all properties except for homesteads. ${ }^{\text {xix }}$ In a news release, the mayor explained that " I now believe that it is absolutely necessary to provide immediate tax relief to offset escalating property values across the remaining tax classifications." ${ }^{x x}$ Table 3 shows that this was achieved by cutting the tax rate on land on all property types, except on homesteads, and keeping the tax rate on buildings unchanged. This resulted in a split rate property tax structure that imposed slightly higher tax rates on buildings than on land for residential, commercial, hotel/resort, and industrial properties.

Table 5 shows estimated (and hypothetical) tax savings due to the reductions in land tax rates alone by applying rate cuts to gross land assessments in FY2006. Table 5 also presents the building to land value ratios for all 8 county property classes. Overall, cuts in tax rates on land alone saved taxpayers almost $\$ 7$ million, or nearly $8 \%$ of the projected annual tax bill and, as the mayor desired, every land use class except "homesteads” benefited from the rate cuts. ${ }^{\mathrm{xxxi}}$ However, not all property types received the same degree of tax relief. Hotels/resorts and apartments (which include non-owner occupied condominium units and timeshares), that have the highest building to land value ratios, benefited the least (3.6\% and $4.4 \%$ respectively) while single family residences benefited the most (17.2\%). While shifting tax shares to tourism and visitors may have been in the minds of the mayor and councilmen when the new rates were set, the primary motive for the tax rate cuts on land in 2006 was to provide property tax relief to all property owners, not just to people who live in their own homes. Thus, the inverted property tax structure was not some grand scheme to influence capital investment and land use decisions. ${ }^{\text {xxii }}$ 


\section{Conclusion}

One of the touted virtues of the staid property tax is that it is widely considered to be a stable and reliable source of tax revenue to fund public services. This paper has demonstrated that it can also be used as a political instrument to promote economic and social change, punish undesirable investors, and provide tax relief to local taxpayers at the expense of non-residents.

In the 1960s and until the state government was required by constitutional amendment to turn over the property tax to the counties, Hawaii lawmakers adopted a statewide split-rate property tax system in which land was taxed at a higher rate than improvements. This policy satisfied political goals of the period: namely, to promote economic growth and effect land reform. Whether tax reform accelerated economic growth remains empirically untested. Given that Hawaii (1) had low property tax rates; (2) land reform brought only a small differential in tax rates on land and on improvements; and (3) tax reform was phased in over an extended period, it was unlikely that Hawaii's adoption of the split-rate property tax produced measurable results in accelerating construction and economic growth. Shoup (1978, p. 107) argues that both the level and the ratio of land to building tax rates matter in determining the impact of land value taxation on land use. ${ }^{\text {xxxiii }}$ Tourism growth—-measured by the number of tourist arrivals—at rates averaging 20 percent per year almost surely had a greater impact on economic growth in Hawaii than the state's adoption of the split-rate property tax. Fourteen years later, the plan was repealed when high rates of economic growth became less desirable.

Following its transfer to the counties, the split rate property tax was re-introduced at different times by three of the four counties. Only Maui County has retained the standard property tax structure since 1982. Maui has not suffered from lack of economic growth; indeed, it has experienced faster economic and population growth than the other three counties. Maui 
demonstrates that the property tax is not the most important determinant of capital investment and economic growth.

In the late 1980s, Honolulu County adopted the highly unusual practice of taxing improvements at a higher rate than land to punish foreign investors who were blamed for driving up housing prices in Honolulu even though evidence indicates that it was not foreign investment, but supply constraints, that explains the run-up in housing prices in Honolulu.

Currently two counties—Kauai and Hawaii—apply the split rate property tax to some property types to provide tax relief to mitigate the effects of sharply rising property values. One taxes land at higher rates than improvements; the other taxes improvements at higher rates than land. Both appear to achieve political equilibrium. 


\section{References}

Aguiar, Eloise (2009). “Billionaire upsets his Kahalu’u neighbors,” The Honolulu Advertiser, January 28: B1 and B4.

Banzhaf, H. Spencer and Nathan Lavery, (in press), “Can the land tax help curb urban sprawl: evidence from growth patterns in Pennsylvania,” Journal of Urban Economics.

Bell, Michael E., John H. Bowman, and Jerome C. German , (2009), “The Assessment Requirement for a Separate Tax on Land,” in Dye, Richard F. and Richard W. England, eds. (2009). Land Value Taxation, Theory, Evidence and Practice, Cambridge, MA: Lincoln Institute of Land Policy, May: 171-194..

Burnett, Kimberly, Jill Khadduri, and Justin Lindenmayer (2008). Research on State and Local Means of Increasing Affordable Housing, Prepared for the National Association of Home Builders, Cambridge, MA: Abts Associates, January).

Bourassa, Steven C. (2009). “The Political Economy of Land Value Taxation,” in Dye, Richard F. and Richard W. England, eds. (2009). Land Value Taxation, Theory, Evidence and Practice, Cambridge, MA: Lincoln Institute of Land Policy, May: 195-210. 
Bowman, John H. and Michael Bell (2008). “Distributional Consequences of Converting the Property Tax to a Land Value Tax: Replication and Extension of England and Zhao,” National Tax Journal, Vol. LXI, No. 4, Part 1, December: 593-607.

Chapman, Jeffrey and Rex L. Facer II (2005). “Connections Between Economic Development and Land Taxation,” Land Lines, Vol. 17, No. 4, October at http://www.lincolninst.edu

Chuan, Ray (2004). The Task Force Plan at

http://homepage.mac.com/juanwilson/islandbreath/06-economy/economy04Reales

City and County of Honolulu, Real Property Assessment Division (2008). Real Property Tax Rates in Hawaii, Fiscal Year July 1, 2008 to June 30, 2009, Honolulu: Administration/Technical Branch, July 28 at https://www.realpropertyhonolulu.com/

Coffman, Makena and Ilan Noy (2009). A Hurricane's Long-Term Economic Impact: the Case of Hawaii’s Iniki. Department of Economics, University of Hawaii at Manoa, Working Paper No. 09-5, June at http://www.economics.hawaii.edu/research/workingpapers/workingpapers.html

Coffman, Tom (2003). The Island Edge of America, A Political History of Hawaii, Honolulu: University of Hawaii Press.

Cohen, Jeffrey P. and Cletus C. Coughlin (2005). “An Introduction to Two-Rate Taxation of Land and Buildings,” Federal Reserve Bank of St. Louis Review, May/June: 359-374. 
Cooper, George and Gavan Daws (1985). Land and Power in Hawaii: The Democratic Years. Honolulu: Benchmark Books.

County of Kauai, Department of Finance, News Release (2005), Mayor Seeks the Largest Tax Rate Reduction in Island History, May 6 at http://www.kauai.gov/Portals/0/Mayor/PIO/PR_Archives/2005/NR05-06-

05\%20_Mayor\%20seeks\%20largest\%20tax\%20rate\%20reduction\%20in\%20island\%20history_. pdf

Daws, Gavan (1968). Shoal of Time, A History of the Hawaiian Islands, Honolulu: University of Hawaii Press.

Dye, Richard F. and Richard W. England, eds. (2009). Land Value Taxation, Theory, Evidence and Practice, Cambridge, MA: Lincoln Institute of Land Policy, May.

Eagle, Nathan (2008), “Property tax reform bill proposed,” The Garden Island, June 2. : A1 and A7.

England, Richard W. (2004), "Property Tax Reform and Smart Growth,” Land Lines, Vol. 16, No. 1, January at http://www.lincolninst.edu 
England, Richard W. (2003), "State and Local Impacts of a Revenue-Neutral Shift from a Uniform Property to a Land Value Tax: Results of a Simulation Study,” Land Economics, 79 (1), February: 38-43.

England, Richard W. and Min Qiang Zhao (2005), “Assessing the Distributive Impact of a Revenue-Neutral Shift from a Uniform Property Tax to a Two-Rate Property Tax with a Uniform Credit,” National Tax Journal, Vol. LVIII, No. 2, June: 247-260.

Finnegan, Tom (2008). “Kauai Plan Would Revise Property Tax,” Starbulletin.com, May 31 at http://archives.starbulletin.com/

Fry, Maxwell J. and James Mak (1984). “Is Land Leasing a Solution to Unaffordable Housing? An Answer from Fee Simple versus Leasehold Property Price Differentials in Hawaii,” Economic Inquiry, Vol. 22, No. 4, October: 529-549.

Gardner, Robert W. and Eleanor C. Nordyke (1974). The demographic situation in Hawaii, Papers of the East-West Population Institute, Number 31, Honolulu: East-West Center, June.

Hartzok, Allana (1997). "Pennsylvania’s Success with Local Property Tax Reform: The Split Rate Tax,” The American Journal of Economics and Sociology, April: 205-13.

Hawaii State Archives, Correspondence of the Attorney General. 
Hitch, Thomas Kemper (1992). Islands in Transition: The Past, Present, \& Future of Hawaii's Economy, Honolulu: First Hawaiian Bank (distributed by the University of Hawaii Press).

Kato, Andrew, Sally Kwak, and James Mak (2009). Using the Property Tax to Appropriate Gains from Tourism, Paper presented at the $102^{\text {nd }}$ National Tax Association Meeting in Denver, Colorado, November 12-14, forthcoming in the Journal of Travel Research.

King, Samuel and Randall Roth (2006). Broken Trust, Honolulu: University of Hawaii Press.

LaCroix, Sumner (1992). “Can Government Make Housing Affordable?” in Randall W. Roth, ed., The Price of Paradise: Lucky We Live Hawaii? Honolulu: Mutual Publishing:135-140.

LaCroix, Sumner, James Mak and Louis Rose (1995). "The Political Economy of Urban Land Reform in Hawaii," Urban Studies, Vol. 32, Vol. 6: 999-1015.

LaCroix, Sumner and Louis A. Rose (1989). "Urban Land Price: The Extraordinary Case of Honolulu, Hawaii," Urban Studies, 26(3): 301-314.

Lee, Anne Feder (1993). The Hawaii State Constitution, A Reference Guide. Westport, Conn.: Greenwood Press. 
Mak, James (2008). Developing a Dream Destination: Tourism and Tourism Policy Planning in Hawaii, Honolulu: University of Hawaii Press.

Mak, James (1992). “Why would government force landowners to sell their land to lessees?” in Randall W. Roth, ed., The Price of Paradise: Lucky We Live Hawaii? Honolulu: Mutual Publishing: 189-194.

Mak, James and Marcia Y. Sakai (1992). “Is foreign investment good or bad for Hawaii?” in Randall W. Roth, ed., The Price of Paradise: Lucky We Live Hawaii? Honolulu: Mutual Publishing: 33-38.

Meller, Norman (1992). “Policy Control: Institutionalized Centralization in the Fiftieth State,” in Zachary A. Smith and Richard C. Pratt, eds. Politics and Public Policy in Hawaii, Albany: State University of New York Press: 13-26.

Nordyke, Eleanor C. (1989). The Peopling of Hawaii, $2^{\text {nd }}$ edition, Honolulu: University of Hawaii Press.

Oates, Wallace E. and Robert M. Schwab. (1997), “The Impact of Urban Land Taxation: The Pittsburgh Experience,” National Tax Journal, Vol. 50, March: 1-21.

Ordway, Nick (1993). "Is it the responsibility of the state and county government to make housing affordable,” The Price of Paradise, vol II, Honolulu: Mutual Publishing: 125-130. 
Plassmann, Florenz and T. Nicholaus Tideman (2000), “A Markov Chain Monte Carlo Analysis of the Effect of Two-Rate Property Taxes on Construction,” Journal of Urban Economics, 47, No. 1, March: 216-247.

Quirk, Jim (2008a), “Low turnout for property tax meeting,” West Hawaii Today, April 26 at http://www.westhawaiitoday.com/articles/2008/04/26/local//local03.txt

Quirk, Jim (2008b), “Assessments, taxes go up,” West Hawaii Today, March 19 at http://www.westhawaiitoday.com/articles/2008/03/19/local//local01.txt

Quirk, Jim (2008c), “Property tax relief plan,” West Hawaii Today, April 2 at http://www.westhawaiitoday.com/articles/2008/04/02/local//local02.txt

Scontras, Lisa. (2009), “Investors looking toward the future,” The Honolulu Advertiser, January 18: R1.

Shoup, Donald C. (1978). “The Effect of Property Taxes on the Capital Intensity of Urban Land Development,” in George F. Break, ed., Metropolitan Financing and Growth Management Policies, Principles and Practice, Madison: The University of Wisconsin Press: 105-132. 
State of Hawaii Department of Business, Economic Development and Tourism (DBEDT)

(2006), 2005 State of Hawaii Data Book, Honolulu: DBEDT at

http://hawaii.gov/dbedt/info/economic/databook/db2005/

State of Hawaii Department of Education (1968), Index to the Honolulu Advertiser and Honolulu Star Bulletin 1929-1967, Vol. IV, Honolulu.

State of Hawaii Tax Review Commission (1984). A Comparative Review of Hawaii’s Fiscal System, 1965-1981 Staff Working Paper No. 2, Honolulu, Department of Taxation.

Supreme Court of Hawaii (2007). County of Kauai v Baptiste, August 6 at http://bulk.resource.org/courts.gov/states/Haw/27351.htm

Tax Foundation of Hawaii (annual: 1968-1979). Government in Hawaii: A Handbook of Financial Statistics, Honolulu.

Tax Foundation of Hawaii (1969a). A Compendium of Governmental Finances in Hawaii, 19491968, Honolulu.

U.S. Advisory Commission on Intergovernmental Relations (ACIR) (1989), "Intergovernmental Fiscal Relations in Hawaii," in Tax Review Commission, Working Papers and Consultant Studies, vol. 2, December, Honolulu: State of Hawaii, Department of Taxation:139-314. 
Youn, Jacy L. (2003). “Kauai’s real estate boom—is it hurting locals,” Hawaii Business, July at http://www.hawaiibusiness.com/Hawaii-Business/July-2003/Good-Times/

Zimmerman, Malia (2007), “Kauai Residents’ Property Tax Revolt Case Goes to Hawaii Supreme Court,” Hawaii Report, February 16 at http://www.hawaiireporter.com/story.aspx?15cfba4f-a5d8-4c9f-b865-c5cc480da59f 
Table 1

Property Tax Rates in Hawaii by Property Type in 1965

(Per \$1,000 Net Taxable Property)

\begin{tabular}{llllll}
\hline & \multicolumn{2}{l}{ State Average } & & \multicolumn{2}{l}{$\begin{array}{l}\text { Highest vs. Lowest Amongst } \\
\text { Counties }\end{array}$} \\
\hline Property Type & Land & Improvements & Ratio & Land & Improvements \\
Residential & $\$ 18.16$ & $\$ 16.32$ & 1.1127 & $\$ 18.47-\$ 15.64$ & $\$ 16.68-\$ 14.08$ \\
Hotel/Apts. & 18.39 & 16.57 & 1.1098 & $\$ 18.86-\$ 15.64$ & $\$ 16.97-\$ 14.08$ \\
Commercial & 18.37 & 16.50 & 1.1133 & $\$ 18.83-\$ 15.73$ & $\$ 16.96-\$ 14.15$ \\
Industrial & 18.21 & 16.33 & 1.1151 & $\$ 19.84-\$ 15.99$ & $\$ 17.14-\$ 14.39$ \\
Agricultural & 16.95 & 16.95 & 1.0000 & $\$ 17.90-\$ 15.00$ & $\$ 17.90-\$ 15.00$ \\
Conservation & 17.41 & 17.41 & 1.0000 & $\$ 17.90-\$ 15.00$ & $\$ 17.90-\$ 15.00$ \\
\hline
\end{tabular}

Notes: (1) Hawaii County had the highest tax rates and Maui County had the lowest rates for all property types. (2) Section 8 HRS 248-2 requires a single rate to be applied to agricultural and conservation properties.

Source: Tax Foundation of Hawaii, Government in Hawaii: A Handbook of Financial Statistics (annual). 
Table 2

Property Tax Rates on Improved Residential Properties in Honolulu FY 1989-FY1999 (\$ per \$1,000 net taxable property)

\begin{tabular}{lrrrrrrrrrrr} 
& \multicolumn{1}{c}{ '89 } & \multicolumn{1}{c}{ '90 } & \multicolumn{1}{c}{ '91 } & \multicolumn{1}{l}{ '92 } & \multicolumn{1}{c}{ '93 } & \multicolumn{1}{c}{ '94 } & \multicolumn{1}{l}{ '95 } & \multicolumn{1}{l}{ '96 } & \multicolumn{1}{l}{97} & \multicolumn{1}{c}{98} & \multicolumn{1}{c}{99} \\
Land & $\$ 6.09$ & $\$ 6.09$ & $\$ 4.70$ & $\$ 3.25$ & $\$ 3.12$ & $\$ 3.12$ & $\$ 3.12$ & $\$ 3.12$ & $\$ 3.12$ & $\$ 3.12$ & $\$ 3.49$ \\
Buildings & 6.56 & 6.56 & 4.95 & 4.09 & 3.92 & 3.92 & 3.92 & 3.92 & 3.92 & 3.92 & 3.49 \\
Bldgs/Land & 1.08 & 1.08 & 1.05 & 1.26 & 1.26 & 1.26 & 1.26 & 1.26 & 1.26 & 1.26 & 1.00
\end{tabular}

Source: City and County of Honolulu, Department of Budget \& Fiscal Services, Real Property Assessment Division at https://www.realpropertyhonolulu.com/portal/rpadcms/Reports?parent=REPORTS\&code=-1 
Table 3

Property Tax Rates in Kauai County: FY 2006 vs FY 2005 (\$ per \$1,000 net taxable property)

$\underline{\text { Land Use Class }}$

Single family residential

Apartment

Commercial

Industrial

Hotel and Resort

Agricultural

Conservation

Homestead

\begin{tabular}{|c|c|c|c|c|c|}
\hline \multicolumn{2}{|c|}{ Land } & \multicolumn{2}{|c|}{ Buildings } & \multicolumn{2}{|c|}{ Buildings/Land } \\
\hline 2006 & 2005 & 2006 & 2005 & 2006 & 2005 \\
\hline$\$ 4.00$ & $\$ 5.14$ & $\$ 4.30$ & $\$ 4.30$ & 1.08 & .84 \\
\hline 6.95 & 8.20 & 7.95 & 7.95 & 1.14 & .97 \\
\hline 6.95 & 8.20 & 7.95 & 7.95 & 1.14 & .97 \\
\hline 6.95 & 8.20 & 7.95 & 7.95 & 1.14 & .97 \\
\hline 6.95 & 8.20 & 7.95 & 7.95 & 1.14 & .97 \\
\hline 6.95 & 7.60 & 4.30 & 4.30 & .62 & .57 \\
\hline 6.95 & 8.10 & 4.30 & 4.30 & .62 & .53 \\
\hline 4.00 & 4.00 & 3.44 & 3.44 & .86 & .86 \\
\hline
\end{tabular}

Notes: 1. Apartment includes non-owner occupied units in multi-unit residential buildings, condos, and timeshares.

2. Homestead properties are used as owners’ principal residences.

Source: City and County of Honolulu, Department of Budget \& Fiscal Services, Real Property Assessment Division. 
Table 4: Gross Assessed Property Tax Values for Residences, Kauai County FY1993-FY2009

(Assessed Value Per Parcel, in thousands \$)

\begin{tabular}{|l|rrrrrr|}
\hline Property Type & FY1993 & 1997 & 2000 & 2003 & 2006 & 2009 \\
\hline Single Family & 207 & 209 & 188 & 252 & 528 & 712 \\
Apartment & 247 & 186 & 169 & 206 & 489 & 485 \\
Homestead & 192 & 210 & 182 & 207 & 446 & 575 \\
\hline
\end{tabular}

Source: City and County of Honolulu, Department of Budget \& Fiscal Services, Real

Property Assessment Division, at https://www.realpropertyhonolulu.com/ 


\section{Table 5}

Kauai Property Tax Savings Due to Reductions in Land Tax Rates (FY 2006)

\begin{tabular}{|c|c|c|c|c|}
\hline$\underline{\text { Land Use Class }}$ & $\begin{array}{c}\text { Gross } \\
\text { Bldg/Land Value }\end{array}$ & $\begin{array}{c}\text { Property Taxes at } \\
\text { FY2005 Rates }\end{array}$ & $\begin{array}{c}\begin{array}{r}\text { Savings at } \\
{ }^{2} \\
\text { FY2006 Rates }\end{array} \\
\end{array}$ & $\begin{array}{l}\text { Savings in } \\
\text { Per Cent (\%) } \\
\end{array}$ \\
\hline Single Family & .348 & $\overline{\$ 20,102,226}$ & $\$ 3,452,434$ & $17.2 \%$ \\
\hline Apartment & 2.529 & $12,827,424$ & $5,66,416$ & 4.4 \\
\hline Commercial & .695 & $8,462,430$ & 770,893 & 9.1 \\
\hline Industrial & .725 & $2,518,115$ & 225,465 & 9.0 \\
\hline Agricultural & .256 & $13,671,664$ & $1,021,188$ & 7.5 \\
\hline Conservation & .099 & $3,190,965$ & 297,027 & 9.3 \\
\hline Hotel \& Resort & 2.837 & $14,741,964$ & 530,634 & 3.6 \\
\hline \multirow[t]{2}{*}{ Homestead } & .714 & $16,780,598$ & 0 & 0 \\
\hline & & $\$ 89,423,576$ & $\$ 6,864,057$ & $7.6 \%$ \\
\hline
\end{tabular}

Notes: (1) Calculated by multiplying 2006 gross assessed valuations for land and buildings, separately, by their respective 2005 property tax taxes from Table 3.

(2) Savings are the difference between tax liabilities at FY2006 rates and tax liabilities at FY2005 rates, both using gross assessed valuations in the calculations.

(3) “Apartment” includes non-owner occupied units in multi-unit residential buildings, condos, and timeshares.

(4) “Homestead” properties are used as owners' principal residences.

Source: City and County of Honolulu, Department of Budget \& Fiscal Services, Real Property Assessment Division, at https://www.realpropertyhonolulu.com/

\section{End Notes}

${ }^{\text {i }}$ Quote from Cohen and Coughlin, 2005, p. 359.

${ }^{\text {ii }}$ Pittsburgh, along with few smaller cities in Pennsylvania, has had a graded property tax system since 1913 under which land was taxed at twice the rate of improvements until 1979. In 1979 and 1980, the city of Pittsburgh restructured its property tax system so that land in the city was taxed more than five times the rate on structures. Since the county and the overlying school district also levied property taxes and they did not participate in the graded property tax system, the actual rate differential after 1979 resulted in land in the city being taxed at somewhat more 
than twice the value of improvements. Properties outside the city remained under the conventional property tax system (Oates and Schwab, 1997, pp. 6-8). Tax reform in Pittsburgh raised the tax rate on land and effectively reduced the rate on improvements on new structures (Oates and Schwab, 1997, p.8). In 2001 Pittsburgh ended its split-rate property tax system. A combination of downward inflexibility in tax rates and a subsequent increase in tax burden that led to the end of land value taxation in Pittsburgh (Dye and England, 2009).

iii They also suggest that regressivity can be mitigated by a tax credit on property tax bills.

${ }^{\text {iv }}$ At http://urbantools.org/news/philadelphia-task-force-on-tax-reform-one-step-short.

${ }^{v}$ HRS Sections 246-10, 246-43 require land and improvements to be assessed separately in Hawaii (Brunori and Carr, 2002, p. 11).

vi The ACIR did not provide an estimate of the upward bias. Bowman and Bell (2005) note that Roanoke, Va. also uses the abstraction method.

${ }^{\text {vii }}$ Hawaii does not impose a property tax on personal property.

${ }^{\text {viii }}$ For example, in Honolulu County, land under commercial properties was taxed at $11 \%$ higher than improvements in 1965; the gap widened to $25 \%$ by 1971 ; and to $43 \%$ in 1977 when the law was abolished (Tax Foundation of Hawaii, various years). 
${ }^{\text {ix }}$ The City and County of Honolulu comprises the entire island of Oahu and the northwestern islands of the Hawaiian chain. Hawaii County covers the entire island of Hawaii. Maui County includes the populated islands of Maui, Molokai, and Lanai. The County of Kauai includes the islands of Kauai and Niihau. Hawaii, Maui, and Kauai Counties are collectively referred to as the Neighbor Islands. While the island (and county) of Hawaii (referred to by locals as the "Big Island") is geographically larger than the other islands combined, Oahu is by far the most populous.

× Article VIII, Section 3 of the Hawaii State Constitution. See Lee, 1993, pp. 143-144.

${ }^{x i}$ Also Daws (1968), p. 395.

xii In 1960, Japanese (203,000), Filipinos $(69,000)$, and Chinese $(38,000)$ comprised nearly half of the State's resident population. (Nordyke, 1989).

xiii The State Legislature also passed a landmark land reform bill in 1967 known as "mandatory leasehold conversion” which forced large landowners to sell their fee simple interests under leasehold single family homes to homeowners (King and Roth, 2006, pp. 81-82; LaCroix, Mak, and Rose, 1995; Mak, 1992). The law was highly controversial and challenges made their way to the Hawaii and U.S. Supreme Courts over its public purpose which were decided in the homeowners' favor. Cooper and Daws (1985, pp. 5-6) also noted that the Democrats made changes to land use laws in the 1950s and 1960s which "cut away at the virtually unrestricted 
power of the old major landowners...” On the other hand, they opined (p. 38) that the tax changes on the whole were "rather modest."

${ }^{\text {xiv }}$ Between 1960 and 1970 there was a net migration of 50,000 people into Hawaii, excluding military movements. (Gardner and Nordyke, 1974, p. 29.) This accounted for slightly less than 40 percent of the increase in the resident population between the two years.

${ }^{x v}$ Coffman (2003), pp. 241-244. At Ariyoshi’s urging, the 1977 Legislature also passed a bill requiring a one-year residency requirement for local government employment, a measure that was invalidated by the federal district court.

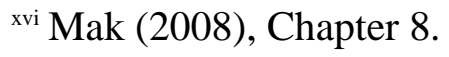

xvii For a list of these stories, see the Index to the Honolulu Advertiser and Honolulu Star Bulletin, 1929-1967 (1968) under the subject headings “Land” and "Property Taxes”; of particular interest are the following Honolulu Star Bulletin stories on April 5, 1963; April 10, 1963; December 5, 1963; February 20, 1964 as well as the Honolulu Star Bulletin/Advertiser story on March 17, 1963.

xviii LaCroix, Mak and Rose (1995, pp. 999-1000) report that in 1967 single-family homes on leasehold land comprised about 26 percent of the total stock of single-family homes, most of them were located in Honolulu County. In the mid-1960s condominiums began to be developed 
some on leasehold land. While (comparable) homes built on leasehold land sold at lower prices than homes built on fee simple land (Fry and Mak, 1984), for property tax purposes, leasehold land in Hawaii is currently assessed as fee simple property with tax bills sent to homeowners (lessees) rather than to landowners (lessors) (Revised Ordinances of Honolulu, Chapter 8, Sec. 86.3.). According to Robert Magota (personal telephone conversation on November 18, 2009) of the Honolulu County Real Property Tax Assessment Division, this method of assessment is common practice in other U.S. localities where there is leasehold residential housing. In theory, this implies that the higher effective land tax on leasehold properties should result in a lower market price for a leasehold property vis-à-vis an identical fee simple property.

xix The Honolulu Star Bulletin ran a story on June 3, 1977 (p. A6) with the caption, "Property tax law intended to foster development is repealed."

${ }^{\mathrm{xx}}$ However, HRS 246A-2 provided that "For a period of eleven years commencing November 7, 1978, the counties shall, by majority agreement of the counties, provide for uniform policies and methods of assessment for the taxation of all real property throughout the State. The policies and methods shall include the assessment, levy, and collection of real property taxes. Upon agreement of the uniform policies and methods to be used for the taxation of all real property, each county shall adopt by ordinance such uniform policy and method of assessment as the real property tax law of the county.”

${ }^{x x i}$ As the fastest growing county in Hawaii, Maui did not appear to need further fiscal incentive to spur development. See ACIR (1989) and Mak (2008), Chapter 8. 
${ }^{\text {xxii }}$ In FY 1983, land under single family residential land was also taxed at a higher rate than buildings. Between FY 1985 and FY2002, the land tax rate was held constant at \$10.00 per $\$ 1,000$ of net taxable property while buildings were taxed at $\$ 8.50$.

${ }_{\text {xxiii }}$ It was noted in public hearings that West Hawaii would be particularly hit hard by the new assessments on residential property improvements because the area has many non-resident (second) homeowners who do not qualify for tax relief under the homeowner category (Quirk, 2008c).

xxiv Higher rates on buildings also applied to apartments but only between FY1989 and FY 1991. In FY 1983, Honolulu levied a higher rate on buildings for single and multi-family residential properties and on apartments and a single rate on all other properties. City and County of Honolulu, Department of Budget \& Fiscal Services, Real Property Assessment Division at https://www.realpropertyhonolulu.com/portal/rpadcms/Reports?parent=REPORTS\&code=-1

${ }^{\mathrm{xxv}}$ Others have pointed the finger at supply constraints. The U.S. Advisory Commission on Intergovernmental Relations (ACIR, 1989, p.239) argued that supply side pressures were likely more important demand considerations, noting that growth in the housing stock did not keep pace with rising population. 
${ }^{\text {xxvi }}$ Personal conversation with Lowell Kalapa. The idea to raise property taxes on homes combined with a tax credit to rebate increases to resident homeowners was one suggested remedy for unaffordable housing in Hawaii during the early 1990s. Ordway (1993), p. 128.

${ }^{\text {xxvii }}$ For instance, Coffman and Noy (2009) found that Kauai's economy did not recover from Hurricane Iniki until 7 to 8 years after the storm, and its population and labor force still have not fully recovered 17 years after the storm.

xxviii See http://www.kauai.gov/Portals/0/Finance_RP/RPT_update_041015.pdf

${ }^{\text {xxix }}$ Recall that homesteaders had a $2 \%$ cap placed on their property tax bills.

${ }^{x x x}$ At http://www.kauai.gov/Portals/0/Mayor/PIO/PR_Archives/2005/NR05-0605\%20_Mayor\%20seeks\%20largest\%20tax\%20rate\%20reduction\%20in\%20island\%20hi story_.pdf

${ }^{\text {xxi }}$ Actual tax bills are calculated using net assessed valuations; net valuations subtract out exemptions. In Table 5 we wanted to show the approximately property tax savings due to the cuts in tax rates on land values alone. Actual tax bills also include revenues lost due to successful appeals.

xxxii Another bill introduced in 2008 (Bill 2274) that would have targeted tourism for heavier taxation did not pass. See Kato, Kwak, and Mak (2009). 
xxxiii See also Burnett, et. al. (2008), p. 160. 